停止中の安全のため枕木に掛る安全装置が取付けられて いる。

\section{S S (セルフスタンド) 式}

ヘッド側にY型レッグをレール面上に立脚せしめコン ベヤを支持する。列車の先頭に作動車を連結, 作動車で レッグを押し上げコンベヤ下に鉱車を格納する。しかし て積込が終り作動車がレッグ部を通過するとレッグは自 動的にレール面に立脚する。

S R（セカンダリレール）式

前者は鉝車がコンベヤの下部に格納されたとき, 荷重 は鉣車で支持されるに対し，本型式は鉱車になんら荷重 をかけることなく列車積みできる方法である。コンベヤ フレーム, 台車, ウオーム減速のエアーホイスト, 安全 爪は S S 式と同一である。

コンベヤのヘッドンレーム近くに門型のVゲートで支 持される。断面はマス型で下盤側は小さな径の車輪で本 線上に乗駕し，天盤則はコンベヤフレームが乗つている。 マス型の内側に本線と同一レールゲージのセカンダリレ 一ルが敷設され，一方は台車に取付けられていっ。

列車は上り勾配のリフトレールに乗込み, 引続きセカ ンダリレール上に乗駕，コンベヤ下部に格納される。

\section{7. 運転 操 作}

（1）本機つ運転操作は通常ヘッドフレームの側面に 集約され，ベルトスピードの調整はバルブ開閉により自
由である。

（2）積込中の諸操作（鉱車引立, 本機の前進等）の 連絡合函はコンベヤマンが司り，エアーホイッスルで指 示する。

（3）積込中ローダとの間隔が開いたため, 機体を前 進させるには，鉱車ハンガを函体に掛けてロコで押す， またはローダで引張る。

\section{8. 使 用積込機}

現用のすべての積込機に使用できるが，とくにコンベ ヤ付バケットローダ “太空” 650型, 800型では常に両コ ンベヤをラップさせ高能率連続積込が可能である。

\section{9.むす び}

以上セルフスタンドコンベヤについて大要を述べた。 坑道掘進機械はその苛酷な使用条件から, 機能が単純で あることも大可な要素であると考える。優秀性能の積込 機を $100 \%$ 稼動させ，もつとも普遍的な鉱車と， S S ב ンベヤローダを組合せた, 後方運搬方式はズリ取り時間 を大幅に短縮して, ローコスト, 急速掘進の達成の一助 となれば誠に幸甚である。現在ますます坑道掘進の急速 化, 合理化の要望は悠しいものであり, 今後さらに技術 研讃をつみ, いつそうの改善, 開発に努力する所存であ ろ。よろしくご指導ご鞭鞋を打願いする次第である。

\title{
セルフスタンデイングコンベヤローダ
}

による水平掘進について

\section{1. 緒言}

神岡鉣山においては, 昭和34年より, 茂住坑, 杤洞坑 円山の既知鉣床下底部の確認および新鉱床の探鈗と, そ の下部開発, 特に茂住坑においては索道運搬を廃止して 坑内運搬に切換える運搬合理化のために $3,000 \mathrm{~m}$ に達す る長距離掘進を迅速に開さくする必要に迫られた。

したがつて, 従来より坑道掘進と比較して穿孔・ズリ 取り等の各作業の研究・改善が重致られ, 昭和39年茂住 通洞において，コンベヤローダ 3 号機の使用により，小 加背 (掘進断面積 $6 \sim 7 \mathrm{~m}^{2}$ ) における月延び $356.3 \mathrm{~m}$ の 記録を樹立し，長距離掘進において 月延び $300 \sim 400 \mathrm{~m}$ が常時可能となつた。

* 三井金属捈業株式会社神岡釯業所茂住坑長
松永恒 忠*

この技術革新を要約すれば

(1) ショートゲージ高速さく岩機の採用

(2) 自家製コンベヤローダの考案および採用

(3) 作業組織および管理の改善

等である。

昭和 $2 \%$ 年以後の掘進技術の変遷を一括すれば第 1 表の とおりである。

\section{2. 後方運搬技術の改善経緯}

ローダによるズリ取りはかなり以前より行なわれてい たが，昭和34年以前は，2 $\mathrm{t}$ バッテリーロコおよび前開 け鉣車またはグランビー鉣車 1 車ごと入替えによる積込 みであつた。

しかしこの方法は 
(1) 鉱車入替え時間が多く, 連続 ズリ取りができない。

(2) 分岐線の設置という余分の作 業を要し, その間引立ての掘進作業 が停止する。

（3）鉱車の入れ替えに際し,脱線， 連結切替元等のため災害の危険が多 い。

(4) 電車, 鈗車の走行距離が長く, 蓄電池の損耗, 車輪・レール摩耗等 の維持費がかさむ。

等の問題点があり, 月間進行長も 2 方操業で $70 \mathrm{~m} か ゙$ 限度であつた。した がつて，増谷通洞の開さくにあたつ てローダとスラッシャトレンの組合 せを採用した。スラッシャトレンは 昭和34年 3 両編成で出発し，その後 逐次連結車数の増加, リモコン化, ホッパー台車の固定化などの改造を 重衫昭和 38 年 7 月 4 方/日操業に おいて $260 \mathrm{~m} /$ 月を記録した。

しかし，なおこの方式はつぎのよ うな久点が指摘された。

(1) 大塊の処理が困難であるう え，鉱車のジョイント部にスラッシ ヤの刃先を引掛けて持ち上げ，脱線 等の事故を起こす。

(2) 車数を増加するとスクレーパ の能力がローダに拉よばずローダマ ンの時間待ちが多くズリ取り時間が 長くなる。

(3) 根本的にズリの引きずり運搬 であるため, 騒音も大きく摩耗変型 等による鉱車の破損が多い。

(4) ワイヤロープの振れや鉱車か らの落石, 時にはスラッシャの転落 があり，保安上好ましくない。

これらを解決するためにコンベヤ ローダ方式が採用された。

\section{3. セルフスタンデイングコン ベヤローダ掘進の採用}

（1） 1 本レッグ型コンベヤロー 夕゙ $\left(1.6 \mathbf{m}^{3}\right.$ 鉱車 8 車積 1 号機)

スラッシャトレンの問題点を解決 するため 1 発破のズリを 1 トレンで 処理し，高さ，長さが余り大きくな

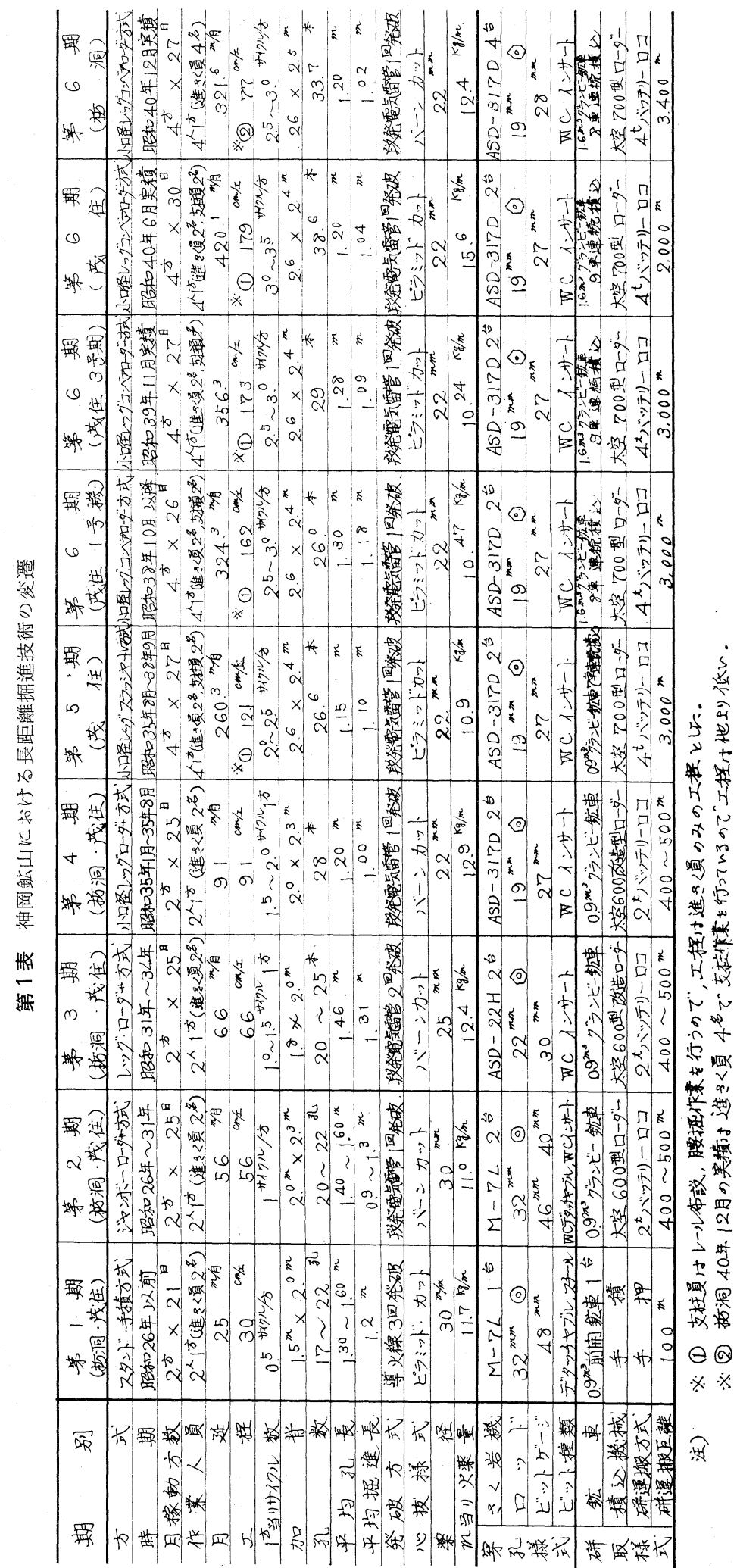



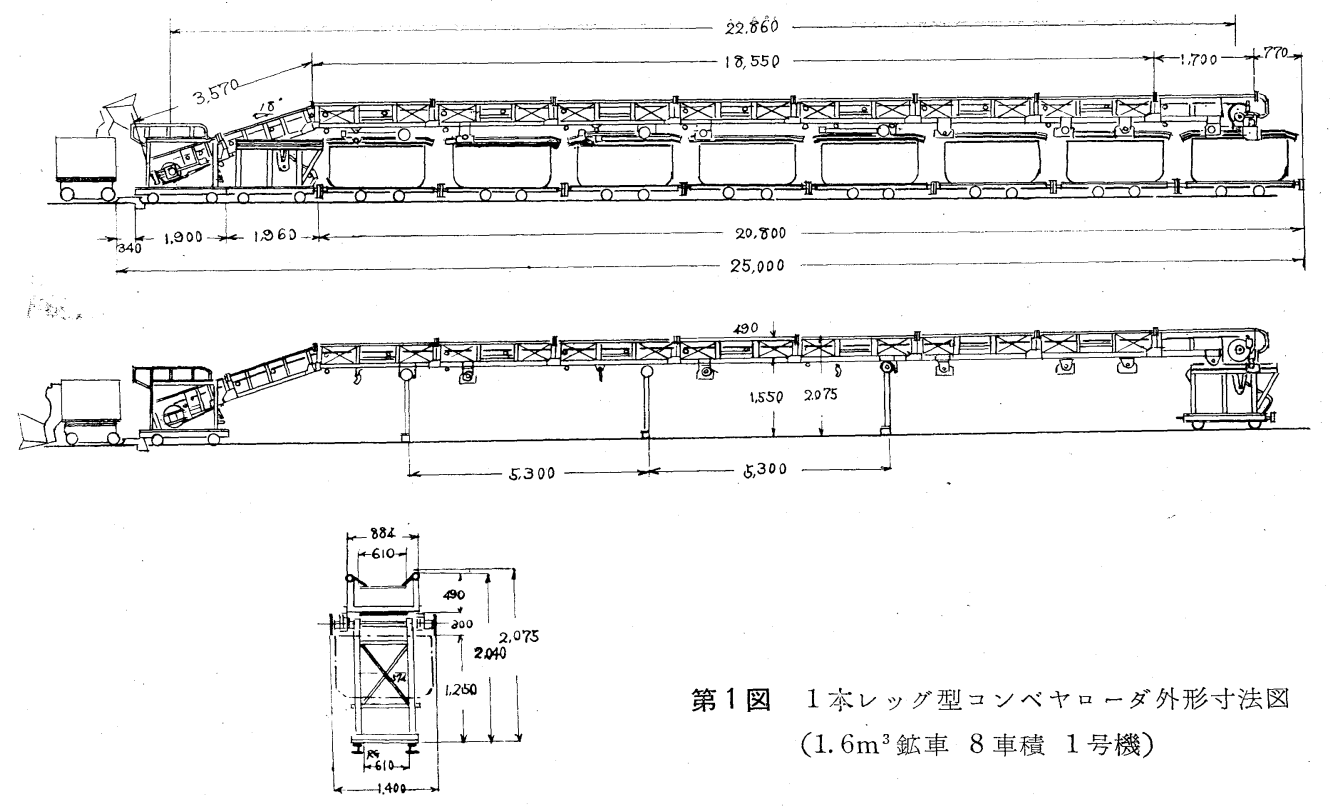

第1図 1 杢レッグ型コンベヤローダ外形寸法図 (1. $6 \mathrm{~m}^{3}$ 鉣車 8 車積 1 号機)

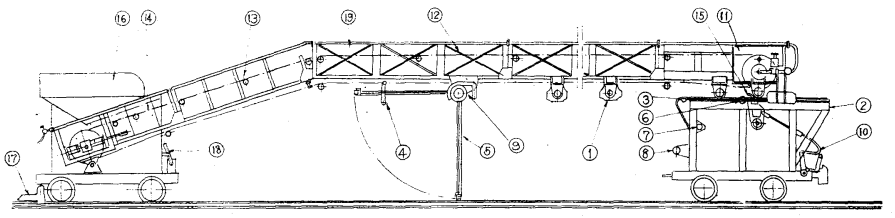

付属機械 ローダ: 太些7 700 型ローダ, 電気機関車 : $4 \mathrm{t}$ 箧池機関車 釷車 : $1.6 \mathrm{~m}^{3}$ グランビー钩車 8 車

第2図 セルフスタンディングコンベヤローダ

1 本レッグ型( 1 号機) 構造図

らないように $1.6 \mathrm{~m}^{3}$ 鉣車 8 車積のコンベヤローダを採用 した。

1 号機の特長は，コンベヤフレームの支持方式にあ る。すなわち鉣車の函体による支持と折たたみ式のレッ グによる支持の両能力を備え, コンベヤ下へ列車を押込 むと自動的にレッグ支持から函体支持に切替えられ，ま た，鈗石を積込みながら列車をコンベヤの下から引出す と自動的にレッグ支持に切替えられる（第 1，2図）。

この 1 号機を昭和 38 年 10 月より茂住通洞に投入し, 10 月 $298.4 \mathrm{~m} /$ 月, 11 月 $324.3 \mathrm{~m} /$ 月とつぎつぎとスラッシ ナトレンの掘進記録を更新した。

この 1 号機は支持脚が 1 本型であり滑動できないので 前後方式には弱く，ホッパー台車にストッパーがあるに もかかわらず，ローダで積込む際の衝撃で脚部の損傷故 障もしばしば発生した。

またフレームの受けローラーに両フランジをつけ左右 の脱落防止を図つたところ，軌道の咀凸や左右のふれの ため逆に鉱車のフレーム受レールが, 受けローラーに合 致せず，外れることがあつた。
第 2 図付表 部分名称表

\begin{tabular}{|c|c|c|c|}
\hline 部分 & 称 & 部分 & 称 \\
\hline \begin{tabular}{l|l} 
(1) \\
(2) \\
(3) \\
(4) \\
(5) \\
(6) \\
(7) \\
(8) \\
(9)
\end{tabular} & 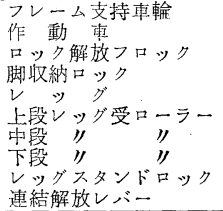 & 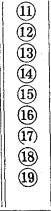 & 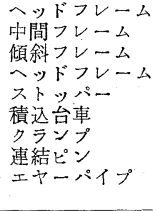 \\
\hline
\end{tabular}

\section{（2）Vレッグ型コンベヤローダ}

\section{(1. $6 \mathrm{~m}^{3}$ 鉱車 9 車積 3 号機)}

1 号機は好成績を収めたが，1年後更につぎの改善を 加え 3 号機を製作した。

(1) 支持脚をVレッグとし，かつ下端ローラーを左右 連続として軌道面を滑動できるようにし鉱車のない時で も移動を可能にした。

(2) フレーム受けローラーはフランジを廃止し平ロー ラーとし，支持レールからのローラーの脱落を防止する ため鉱車の内側に入るよらにガイドプレートを設けた。

(3) フレームは $3 \mathrm{~m}$ ごとに分割して, センターボルト で接続し，両側をスプリングワイヤーで締め付け，自在 接手とし，少々の曲線部は通過できるようにした。

(4) コンベヤフレームのアングルは強度を増すために 2"より $2 \frac{1}{2} 2^{\prime \prime}$ に増強した。

(5) コンベヤは鉱車 8 車積を 9 車積に延長し， 1 発破 当たり $1.1 \mathrm{~m}$ (加背 $2.4 \times 2.6$ ) に延びても 1 トレインで 積込可能となつた。

以上の改善を加えて，コンベヤローダ 3 号機は昭和39 年 9 月に完成し, 10月より掘進切羽に投入し, 昭和 39 年 11 月 $356.3 \mathrm{~m} /$ 月, 翌 40 年 6 月 $420.1 \mathrm{~m} /$ 月と掘進記録を 
第 2 表 長距離掘進用コンベヤローダ機能表

\begin{tabular}{|c|c|c|}
\hline 別 & 1 本レッグ型 1 号機 & Vレッグ型 3 号機 \\
\hline 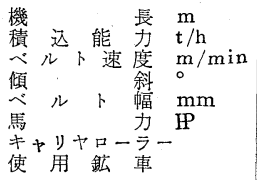 & $\begin{array}{c}25 \\
33 \\
44 \\
18 \\
600 \\
7.5 \\
\text { フラッr } \\
1.6 \text { m鉣車 } 8 \text { 車積 }\end{array}$ & $\begin{array}{c}28 \\
33 \\
44 \\
18 \\
600 \\
7.5 \\
\text { フラット } \\
1.6 \mathrm{~m}^{3} \text { 鉱車 } 9 \text { 車積 }\end{array}$ \\
\hline
\end{tabular}

更新した（第1,2表，第3,4図）。

このコシベヤローダ 3 号機の操作方法は次のと抢りで ある。コンベヤローダによる積込は第 4 図のごとくコン
ベヤは支持レッグを持つた鉱車および鉱車の最後尾に連 結された作動車により支えられた状態から始妨らる。 積込みが進み鉱車が順次引出され, 最後尾の作動車が V 型レッグ格納位置に達すると，レッグ支持ローラーは 作動車レール(7)の傾斜に従い,レッグの自重で下り, 補” 助脚(4)の先端部ローラ(14)はフレームに組まれた案内溝(6) を滑りレッグスタンドロックの位置に至り，ロックさ れ、レッグはV 型に固定され，レッグローラー—は軌道 レール面に達して作動車に代つてコンベヤを支持する。 同じ方法でV型レッグをつぎっぎに下し，作動車が
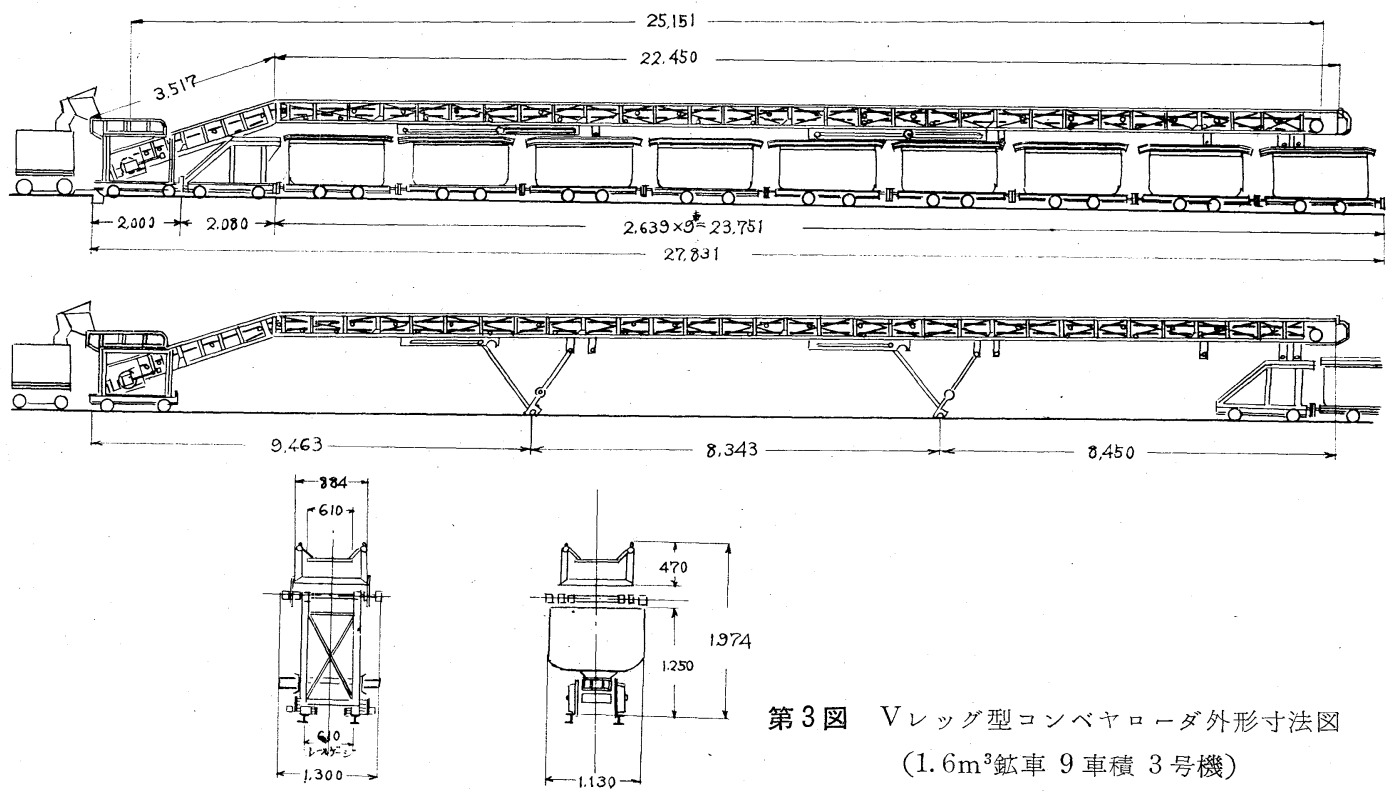

第 3 図 Vレッグ型コンベヤローダ外形寸法図

(1. $6 \mathrm{~m}^{3}$ 鉱車 9 車積 3 号機)
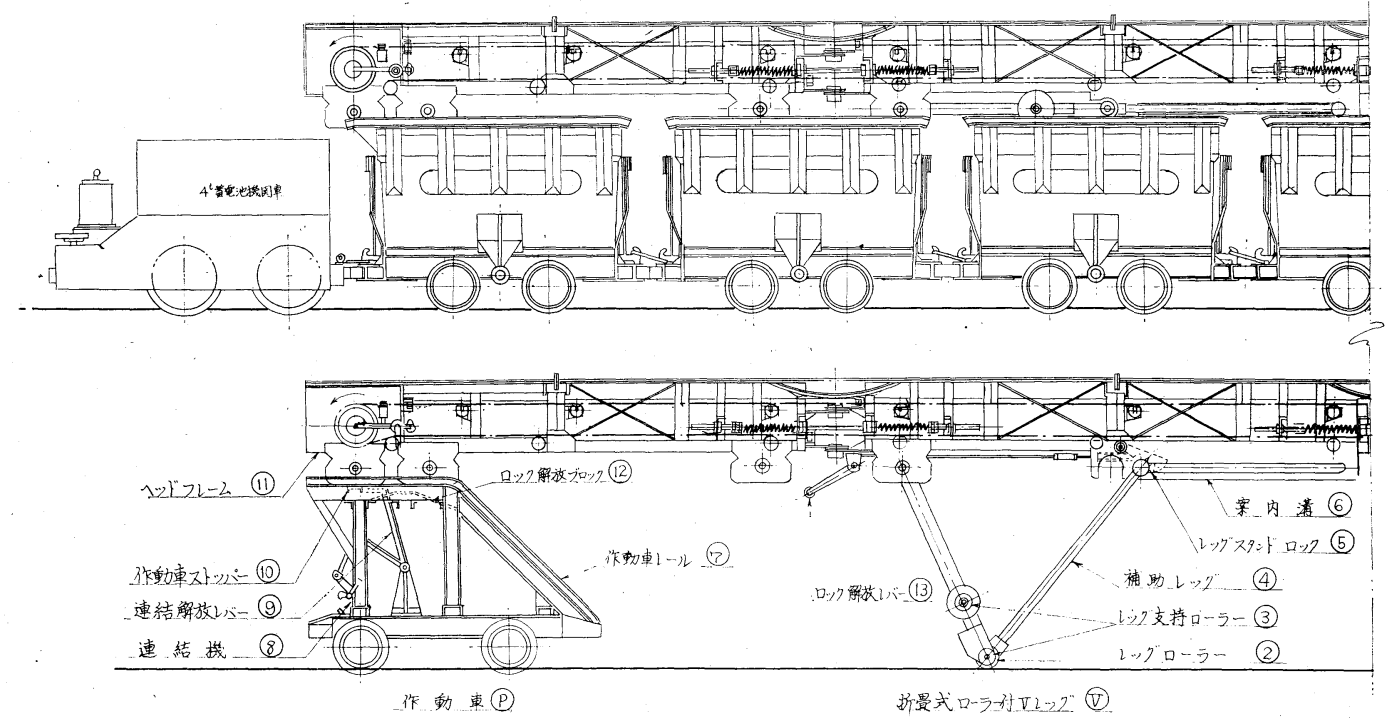

第 4 図 Vレッグ型コンベヤローダ構造図

(1. $6 \mathrm{~m}^{3}$ 鉱車 9 車積 3 号機) 
コンベヤ先端に達すると，フレーム先端のストッパーに 当たり，コンベヤローダは鉱車とともに発破時の退避位 置まで索引される。その後鉱車と作動車の連結を比離 し、ズリ出しを行なら。

鉱車を押込む時は，鉱車を作動車に連結した後，作動 車抢よび鉱車の支持レールでコンベヤフレームを支えな がら順次押し込まれ作動車がVレッグの手前に達すると 作動車上面のロック解放ブロック店がフレームのロック 解放レバー183押上げて脚スタンドロック(5)を外す。口 ック解放後作動車レール(7は脚支持ローラー(3)を受けて 徐々に脚を持上げる。補助脚の先端ローラー114は案内溝 (6)を滑り，V型脚は直線となりフレーム下に格納され る。

\section{（3） 中距離掘進用コンベヤローダ}

長距離掘進用コンベヤローダの開発ととも亿直線部以 上の中距離掘進に適用するコンベヤローダを製作し効果 を上げている。

1） Vレッグ型中距離コンベヤローダ $\left(0.9 \mathrm{~m}^{3}\right.$ 鉱車 4

第 3 表 中距離掘進用コンベヤローダ機能表

\begin{tabular}{|c|c|c|c|c|c|}
\hline 種 & & 別 & & Vレッグ型 2 号機 & レッグなし型 4 号機 \\
\hline 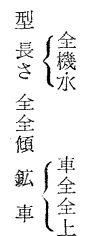 & $\begin{array}{c}\text { 平 } \\
\text { 斜 }\end{array}$ & 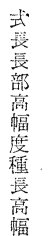 & $\begin{array}{l}\mathrm{m} \\
\mathrm{m} \\
\mathrm{m} \\
\mathrm{m} \\
\mathrm{m} \\
\circ\end{array}$ & 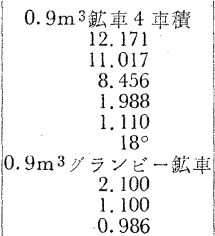 & 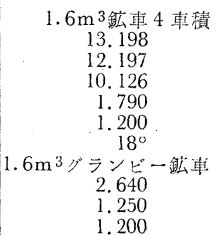 \\
\hline
\end{tabular}

車積 2 号機) $2.0 \times 2.2 \mathrm{~m}$ の加背でズリ運搬距離の短かい 掘進作業で使用するため, 昭和 39 年 5 月 2 号機が製作さ れ，掘進作業を 3 人クルーシステムにて行ない 1 発破の ズリを2 回に分けて处理し, 中距離坑道掘進の急速化に 貢献した。

$$
\text { 上/39実績 } 75.3 \mathrm{~m} \quad 124.3 \text { 工 } 60.6 \mathrm{~cm} / \text { 工 }
$$

(加背 $2.2 \times 2.4$ )

2）脚なし型中距離コンベヤローダ $\left(1.6 \mathrm{~m}^{3}\right.$ 鉣車 4 車 積 4 号機) $2.4 \times 2.6 \mathrm{~m}$ の加背用中距離コンベヤローダを 昭和 40 年 8 月製作し使用中で女る。

このコンベヤローダはVレッグを廃止し, 先頭車と作 動車のみで支持し, ローラーを鉱車に取付け, フレーム 側にガイドを取付けた。
上/42 実績 $90.9 \mathrm{~m}$
129.6工 $70.1 \mathrm{~cm} /$ 工

(加背2. $4 \times 2.6 \mathrm{~m}$ )

\section{4. 現在}

昭和 40 年当時 1 セットであつたコンベヤローダは，現 在 11 セットと増加し, 坑道掘進に活躍している。

なお，コンベヤローダを曲線部に使用できるようにカ ーブドコンベヤローダを研究中であり，以上の技術改善 によりコンベヤローダ掘進の能率向上を更に推進してい る。

\section{参考文 献}

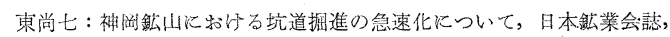
81 卷, 926 号, 昭和 40 年 6 月

\section{南大夕張斜坑の機械化急速掘進について}

\section{1. ま・えがき}

南大夕張炭鉱は昨年, 石炭鉱業審議会答申による「未 開発炭田の開発地域」指定を受け，41年10月開発工事に 着手し，総額 86 億 5,000 万円の資金により年産 90 万 $\mathrm{t}$ の 新鋭原料炭炭鉱を造成中である。

開発方式は地質状況，立地条件等により斜坑方式を採 用し，入気運搬用の第 1 ，第 2 斜坑（全長 $1,328 \mathrm{~m}$ ) 打 よび排気立坑（内径 $5 \mathrm{~m}$, 全長 $403 \mathrm{~m}$ ) の開さくを終了し て, 目下, 斜坑一立坑間の貫通を目指して坑底坑道拉よ び本片坑道の掘さくを鋭意推進中である。

第 1 , 第 2 斜坑は幌内頁岩層内に設定された傾斜 16 度, 掘さく断面積 $18 \mathrm{~m}^{2}$ の大断面斜坑であるが，その急 速掘進を達成するために，42年 3 月よりサイドダンプロ

* 三菱钩業株株式会社南大夕張開発事務所 副長
吉 田 俊 郎*

一ダおよびモノレール式コンベヤを装備して列車積方式 によるズリ処理の機械化を図り, 多サイクルの連続掘進 を推進した結果, 安定的に月延 $200 \mathrm{~m}$ を確保する技術的 方策を確立したのでここにその概要を報告する。

\section{2. 坑道の仕様および設備}

\section{1) 坑道仕様}

全長 $1,328 \mathrm{~m}$, 傾斜 $16^{\circ}$, 掘さく断面積 $18 \mathrm{~m}^{2}$, 有効断 面積 $15 \mathrm{~m}^{2}$ (敷幅 $5.4 \mathrm{~m}$, 高さ $3.6 \mathrm{~m}$ ), 施枠J I S B 5.4 , 3 部材アーチ枠（標準枠間 $1.5 \mathrm{~m}$ )

\section{2）設備}

a. 巻上機; 第 1 斜坑 $640 \mathrm{~kW}$ 複胴 (斜坑掘進中は単 胴巻として使用), ロープ速度 $250 \mathrm{~m} / \mathrm{min}$, 第 2 斜坑： $450 \mathrm{~kW}$ 単胴, ロープ速度 $200 \mathrm{~m} / \mathrm{min}$

b. 鉱車 $; 1.7 \mathrm{~m}^{3}$ 片開きダンプ車, 1 列車 6 両連結坑 